\title{
Effect of materials on HIV/AIDS by the different segment of population in a selected community area
}

Rezaul Karim

From $16^{\text {th }}$ International Symposium on HIV and Emerging Infectious Diseases

Marseille, France. 24-26 March 2010

\section{Background}

On the effect of IEC materials on HIV/AIDS by the different segment of based on mainly popular ongoing IEC campaign i.e. poster, billboard, advertisement on TV and radio, drama etc. People's choice, preference for effective media was sought for future pragmatic endeavour.

\section{Methods}

This study is a descriptive cross-sectional. Respondents from different segment of population were used as a sample. Two hundred people selected as sample size from a community of Gazipur district and using a semistructured questionnaire data was collected on the effect of Information, Education and communication (IEC) materials on HIV/AIDS by the different segment of was collected.

\section{Results}

People admit that $69 \%$ get the information about AIDS from television, contrast with that from both TV and radio $25 \%$ among the respondents $54 \%$ has acquaintance about AIDS for five and more years, $41 \%$ has more than one year. Significantly, 97\% respondents admitted that there is enough importance of IEC materials or mass media to prevent HIV/AIDS. About 63\% respondent told about the route of transmission of AIDS causes for illegal sexual relationship, $26 \%$ told about sex with several partners. And only $3 \%$ indicated that repeated use of injection syringe may cause AIDS. In the field of sigma and discrimination alarmingly $98 \%$ expressed that people show negative attitude towards HIV positive

\footnotetext{
Correspondence: drr_karim@yahoo.com
}

nipsom, Dhaka, Bangladesh

BioMed Central @ 2010 Karim; licensee BioMed Central Ltd. people. The respondents suggest $(69 \%)$ that media can play role by making drama, discussion etc. to aware people. From bi-variate analysis it has been explored that there is strong association with the respondent's education and knowledge of HIV/AIDS $(\mathrm{p}<0.05)$. The marital status of the respondent and knowledge on transmission of HIV/AIDS are statistically associated $(\mathrm{p}<0.05)$.

\section{Discussion}

The study revealed that level of education had positive impact on prevention of HIV/AIDS.

Published: 11 May 2010

doi:10.1186/1742-4690-7-S1-P147

Cite this article as: Karim: Effect of materials on HIV/AIDS by the different segment of population in a selected community area. Retrovirology 2010 7(Suppl 1):P147.

Submit your next manuscript to BioMed Central and take full advantage of:

- Convenient online submission

- Thorough peer review

- No space constraints or color figure charges

- Immediate publication on acceptance

- Inclusion in PubMed, CAS, Scopus and Google Scholar

- Research which is freely available for redistribution

Submit your manuscript at www.biomedcentral.com/submit 